\title{
Article \\ The Lunette with St. Thomas Becket at the Sacro Speco in Subiaco: An Unexpected Presence?
}

\author{
Roberta Cerone
}

Citation: Cerone, Roberta. 2021. The Lunette with St. Thomas Becket at the Sacro Speco in Subiaco: An Unexpected Presence? Arts 10: 58. https://doi.org/10.3390/arts10030058

Academic Editor: Carles

Sánchez Márquez

Received: 22 July 2021

Accepted: 24 August 2021

Published: 30 August 2021

Publisher's Note: MDPI stays neutral with regard to jurisdictional claims in published maps and institutional affiliations.

Copyright: (C) 2021 by the author. Licensee MDPI, Basel, Switzerland. This article is an open access article distributed under the terms and conditions of the Creative Commons Attribution (CC BY) license (https:// creativecommons.org/licenses/by/ $4.0 /)$.
Facoltà di Lettere e Filosofia, Sapienza Università di Roma, 00185 Roma, Italy; roberta.cerone@uniroma1.it

\begin{abstract}
The painting with St. Thomas Becket, St. Stephen and St. Nicholas of Bari that decorates one of the lunettes in the so-called lower church at the Sacro Speco in Subiaco is an enigma from an art-historical point of view, for two reasons. First, on an iconographical level, the lunette interrupts the flow of the story of Benedict's life unfolding systematically on all the walls of the lower church. Second, from the formal point of view, the fresco clearly presents more archaic features than the surrounding Stories of St. Benedict, dating to the end of the thirteenth/beginning of the fourteenth century, and was therefore probably executed in a phase prior to the cycle of Benedict. In the paper, therefore, I will analyse the motivations that led to the preservation of this painting when the hall was renovated and later redecorated in the late thirteenth century, and discuss the hypotheses surrounding patronage. Both aspects will help to better contextualize the reasons for the presence of the image of St. Thomas Becket in a pre-eminent position in the sanctuary of Benedict in Subiaco, a papal bulwark on the borders of the Kingdom.
\end{abstract}

Keywords: Subiaco; St. Benedict of Norcia; Honorius III; medieval monasteries; wall painting

\section{Introduction}

At the beginning of the sixth century, St. Benedict of Norcia, fleeing Rome and worldly temptations, sought refuge in Subiaco in the Aniene valley, as Gregory the Great recounts in the second book of his Dialogues. ${ }^{1}$ Benedict's presence encouraged the development of cenobitic life in the valley with a series of no less than thirteen monasteries founded directly by the saint (Pani Ermini 1981; Fiore Cavaliere 1994, pp. 13-24). Among these, already at the end of the tenth century, the monastery of Santa Scolastica stood out for its importance and became the centre of a vast territory (Cerone 2015, pp. 39-43). From the end of the twelfth century, however, it was the community established at the Sacro Speco that took up Benedict of Norcia's spiritual inheritance, thanks in part to the inspiring presence of Benedict's cave, which was a constant reminder of the sacrifices required by regular life.

The sanctuary of the Sacro Speco, where the lunette with St. Thomas Becket is painted (Figure 1), is linked to veneration of the cave on Mount Taleo where for three years St. Benedict retired as a hermit, before abandoning his solitary existence for a cenobitic lifestyle, trying out the rule that he later established in Montecassino (Figure 2). None of the thirteen original monastic communities took up residence there, but the memory of the cave remained intact over the following centuries and the site soon became a destination for pilgrimage and attracted the euergetism of the popes. 


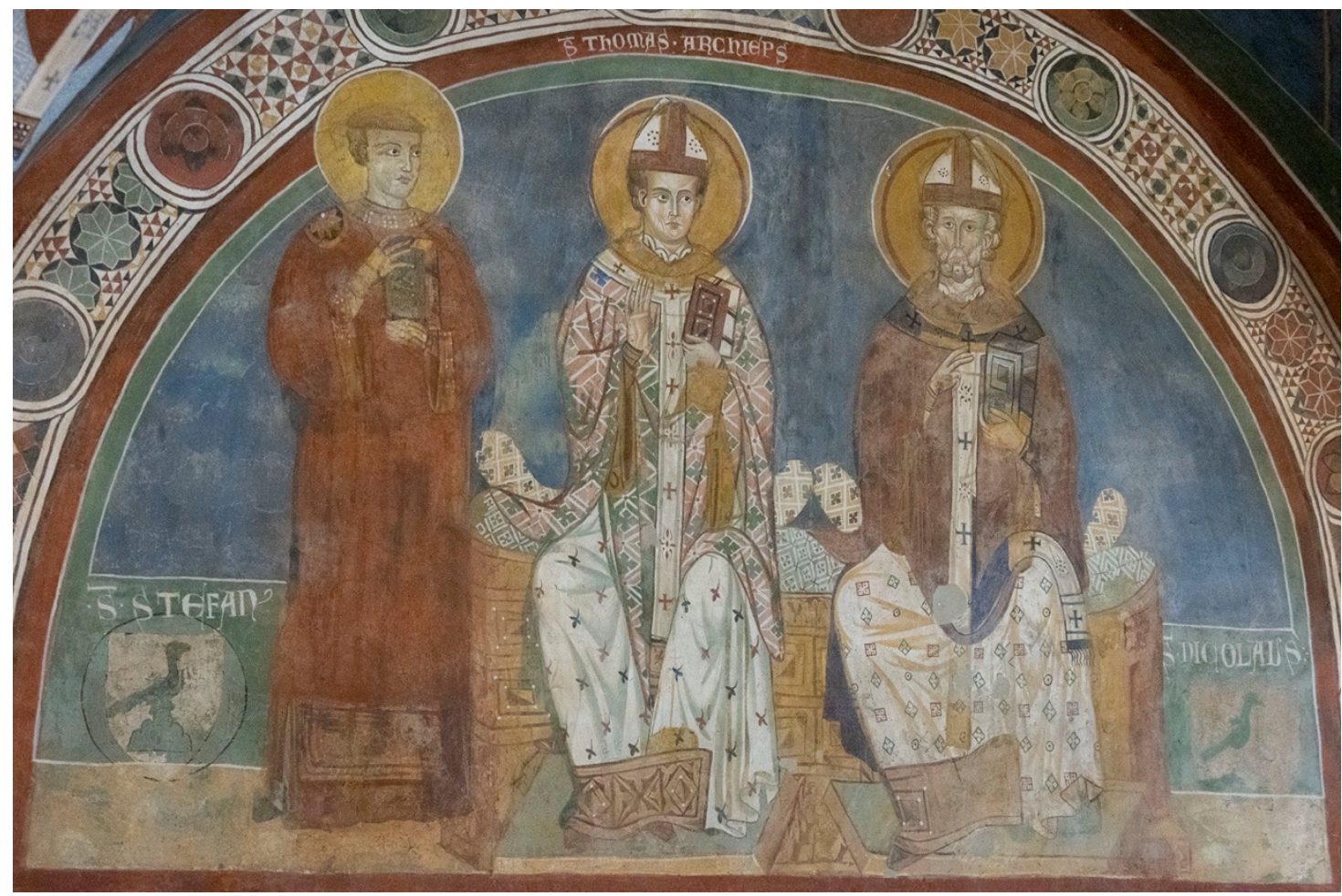

Figure 1. Sacro Speco, Subiaco (Italy), Lower Church. Fresco. Lunette with St. Stephan, St. Thomas Becket, St. Nicholas. Photo: Davide Giannetti.

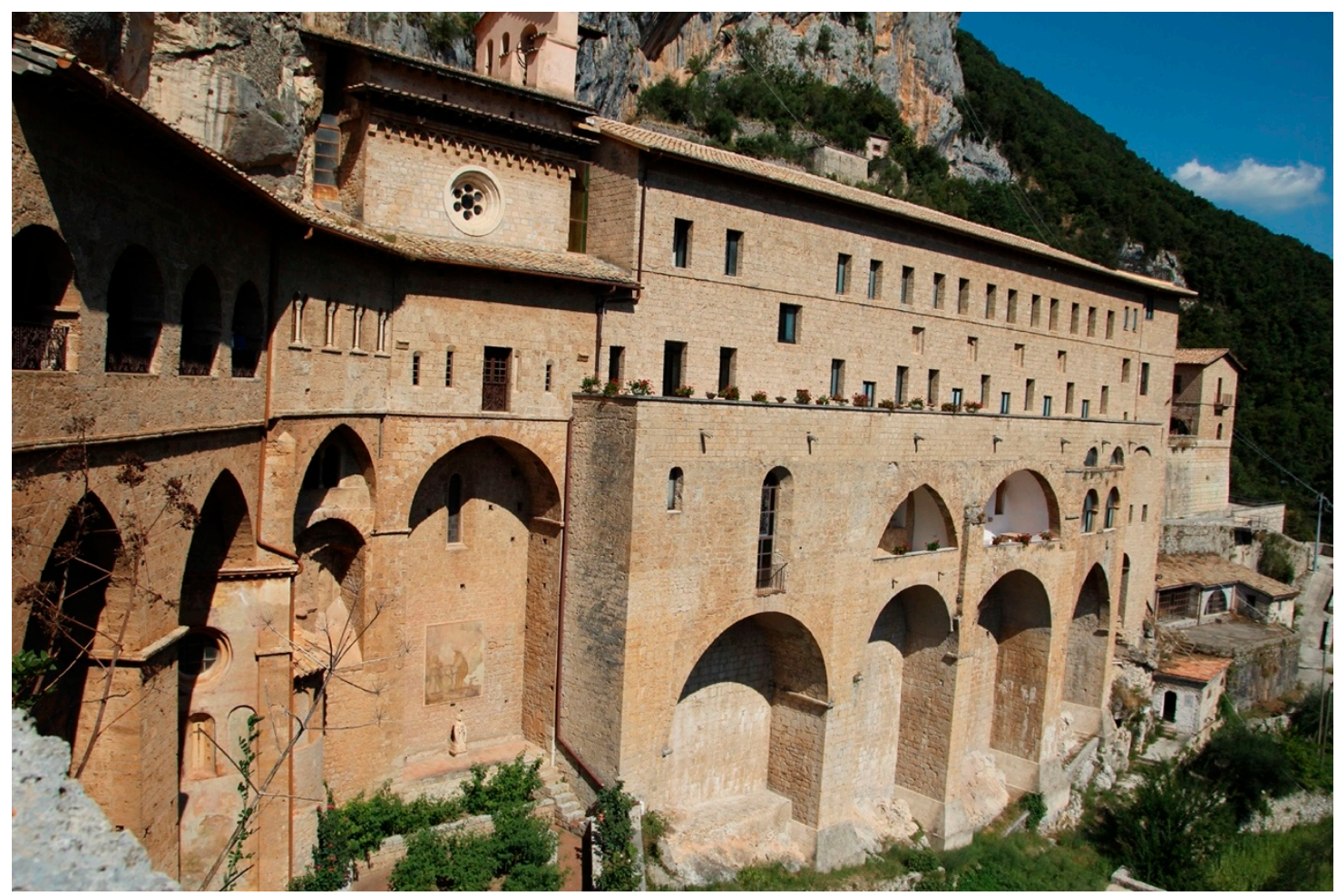

Figure 2. Sacro Speco, Subiaco (Italy). Exterior view. Photo: Roberta Cerone.

Thus it was that, starting from the ninth century, a series of initiatives led to the monumentalization of the cave. ${ }^{2}$ The first intervention, with Pope Leo IV (847-855), involved the construction of some altars, one in honour of the saint and his sister Scholastica and the 
other of Pope St. Silvester (Carucci and Morghen 1991, p. 151). Since at the time there was still no stable community at the site and the system of natural caves was sporadically home to hermits, it is unlikely that the altars were located inside a masonry building; instead, they must have been inside the caves themselves: that in which Benedict had lived, but also that below, known as the cave "of the shepherds", to which the local people flocked to hear him speak (Gregorius Magnus 1847, cols. 128-32).

We must await the eleventh century for further news of the Speco. Under the rule of the Abbots Umbertus (1051-1060) and Iohannes V (1060-1121), a first attempt was made to create an alternative monastic centre to Santa Scolastica, though still under its control. According to the Chronicon, Umbertus built a "beautiful church and a covered crypt", of which no trace remains today (Carucci and Morghen 1991, p. 156). Nothing prevents us from hypothesizing that this was an oratory, small in size but worthy of hosting the prayers of illustrious guests-such as Pope Gregory VII (1073-1085) and the Abbot of Montecassino, Desiderius-who often travelled to visit the holy cave (Carucci and Morghen 1991, p. 163).

The sources attribute to Iohannes V the first authorization to settle at the Sacro Speco, according to a small group of friars under the guidance of the monk Palumbo (Carucci and Morghen 1991, p. 167). This same abbot was also responsible for the arrangement of the key areas of the sanctuary, starting with the Holy Stairs, mentioned in the sources for the first time, which served to ease the path of the faithful as they ascended towards the hermitage (Carucci and Morghen 1991, pp. 173, 176). Iohannes V also renovated the early medieval altars, ruined by damp, and built new ones; the chronicles associate his name, for example, with an altar in honour of the Virgin, as well as a chapel dedicated to St. Romanus, the monk who had taken care of St. Benedict and dressed him in the monastic habit. It is impossible today to define the nature of this place, but we can perhaps guess at its location: immediately above the saint's cave, to commemorate the point from which Romanus lowered the basket with bread for Benedict, as Gregory the Great narrates (Gregorius Magnus 1847, col. 130).

The narrative of the sources thus attests that during the eleventh century a rocky devotional route had now become consolidated, leading upwards to the series of altars in honour of the Virgin, of Silvester, then of St. Romanus and finally to the veneration of the cave. No material traces remain of this primitive arrangement except the fresco with the Virgin and St. Silvester in the Grotta dei Pastori ("Cave of the Shepherds"), dating to between the ninth and tenth centuries (Cristiani Testi 1982, p. 95; Matthiae and Andaloro 1987, p. 196). The refoundation of the sanctuary in the thirteenth century erased the earlier traces and gave the sanctuary the appearance it still partially retains today.

\section{The Thirteenth-Century Refoundation}

The papacy of Pope Innocent III (1198-1216) marks the start of a long phase in which new buildings were constructed next to the caves in a gradual process of monumentalization that lasted until the end of the thirteenth century. The worksite was divided into two distinct phases: the first at the beginning of the century, ending at the time of Gregory IX (1227-1241); the second-more significant-in the second half of the thirteenth century, sealed by the fresco painting of the lower church with the Stories of Benedict by Magister Conxolus, executed at the end of the thirteenth or perhaps the very beginning of the fourteenth century (Giovannoni 1904, pp. 381-88; Righetti Tosti-Croce 1982, pp. 78-86). To correctly contextualize the lunette with St. Thomas Becket both phases should be examined because this was one of the first paintings to decorate the sanctuary, but in the second half of the century it was also significantly restored and even incorporated into the new decorative programme.

In the year 1200, the chronicles record the news of a prior of the Sacro Speco for the first time and thus attest to the presence of a stable monastic community. ${ }^{3}$ Thanks to the support of Innocent III, this group of brothers gained financial independence from the larger monastery of Santa Scolastica with which, however, they continued to share an abbot. The series of letters, dated between 1202 and 1203, that the pope addressed to the 
monks of the Speco, show the admiration for the small brotherhood that followed the rule of Benedict in an exemplary manner, in contrast to the corrupt "twin" community of Santa Scolastica, severely rebuked in other missives (De Prosperis 2008, pp. 18-24). However, it was not just the religious aspects that attracted the attention of Innocent III. Indeed, his intervention should be seen within the context of the pontiff's more general interest in the monasteries of Subiaco, which could guarantee control over the area and loyalty to the nascent Papal States in an area on the border with the Kingdom of Sicily. ${ }^{4}$ This dual motivation, simultaneously symbolic and pragmatic, characterized the relationship between Rome and the monasteries of Subiaco throughout the Middle Ages; equally, the peculiar ties of the popes with this place had already been inaugurated many centuries earlier by Pope Gregory the Great, author of the first biography of Benedict, pointing out to the reader the exemplary character of the monks of the Aniene Valley.

It is not easy to determine with certainty which construction projects were undertaken under Innocent III, but the sanctuary likely continued to maintain its rocky connotation. Probably, as critics have noted for some time, the chapel of the Virgin was erected in this period, at the foot of the Holy Stairs, and the staircase itself was covered to protect the pilgrims who walked along it (Figure 3) (Righetti Tosti-Croce 1982, pp. 78, 81).

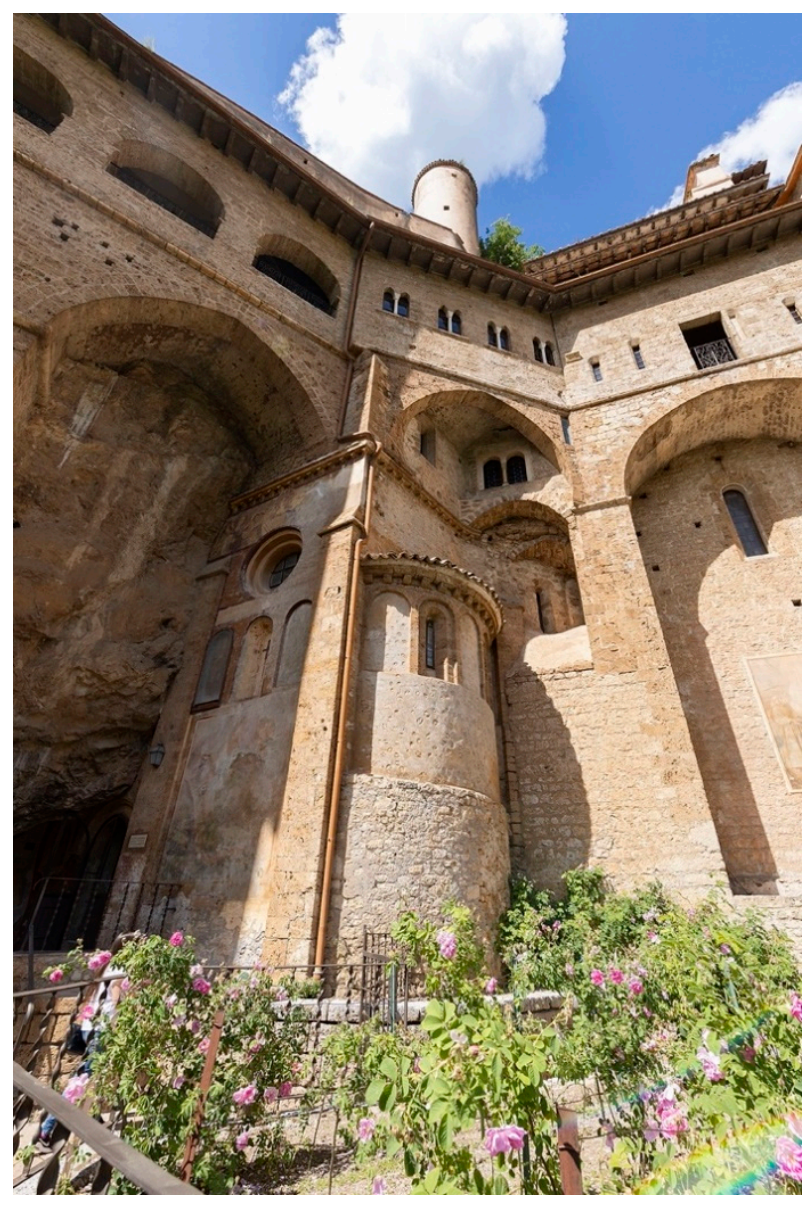

Figure 3. Sacro Speco, Subiaco (Italy). Exterior view with the Chapel of the Virgin. Photo: Davide Giannetti.

To mark the completion of the renovation of the devotional route, as well as to seal these papal initiatives, the north wall of the future lower church was frescoed with the text of the decretal issued by Innocent in 1203, sanctioning the donation of a portion of the income of the castle called Castrum Porciani (near Ferentino) to the monks (Figure 4). This wall marked the point at which the Holy Stairs ended and the descent towards Benedict's 
cave began, and was thus an important place, clearly visible to all, in which to post the manifesto of the papal policy that exalted the monastic community and, at the same time, celebrated the authority of the Pope. The fresco, as well as accurately reproducing the Bull, depicts the figure of the pontiff as a donor intent on holding the document together with St. Benedict, at whose feet kneels the Abbot Romanus (De Prosperis 2008, pp. 21-24; Israel 2004). The latter, obviously, symbolizes the entire community of Subiaco, but it is important to remember that the donation letter was addressed not to the abbot, but to the prior of the Speco, Iohannes, a character to whom we will return precisely in relation to the lunette with Thomas Becket. ${ }^{5}$

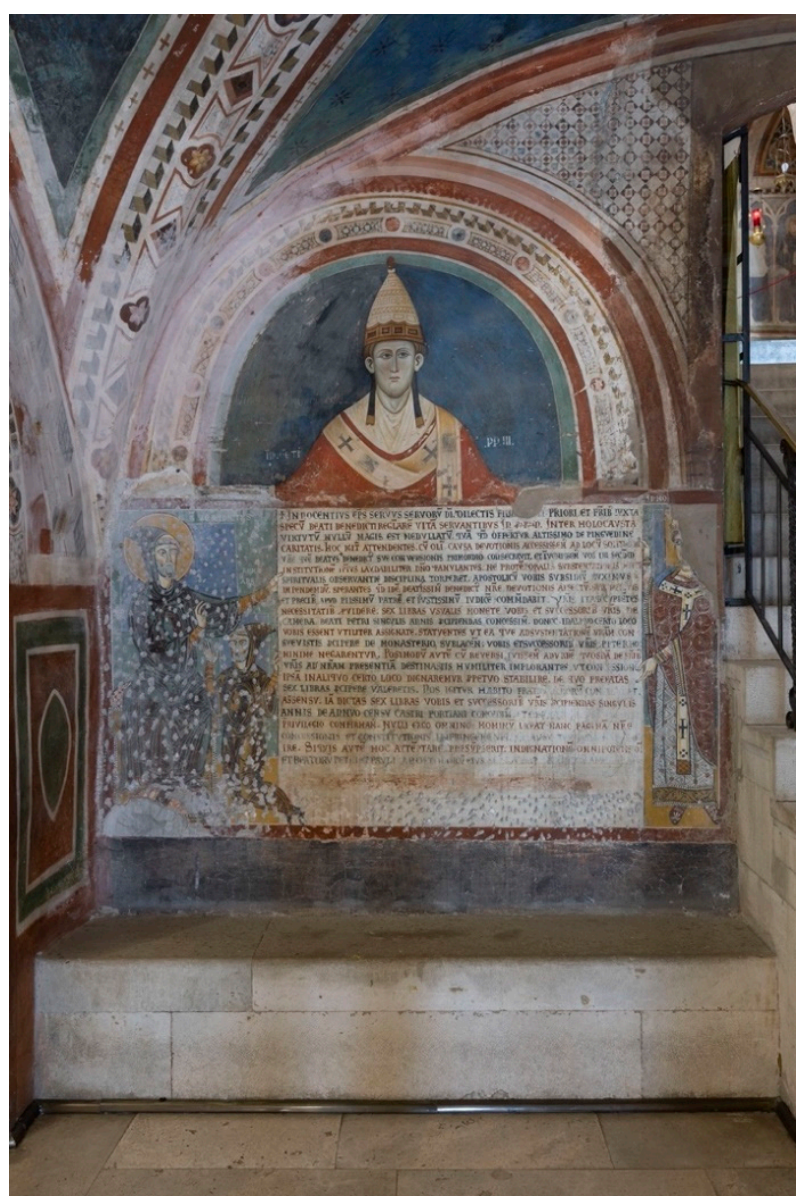

Figure 4. Sacro Speco, Subiaco (Italy), Lower Church. Fresco. Bull of Pope Innocent III. Photo: Davide Giannetti.

The date of the panel with the Bull can be safely dated to 1216, the year of the death of both the abbot and the pontiff, who has a square halo in the painting and is therefore still living. This is thus the oldest fresco in the lower part of the sanctuary after the early medieval fragment in the Cave of the Shepherds, spared when the space was rearranged in the second half of the century, certainly thanks to the exceptional importance of the message conveyed by the painting. In the meantime, under Honorius III (1216-1227) and Gregory IX (1227-1241), Subiaco continued to hold considerable importance on the political stage of the Papal States, as demonstrated by documents and artistic initiatives. Under these two popes, the chapel of St. Gregory was erected and decorated above the chapel of the Virgin (Figure 5) (Righetti Tosti-Croce 1982, p. 82). In the complex iconographical programme of the paintings and in the dedication to St. Gregory the Great, this place reaffirms Subiaco's identity as a bulwark of Rome and exalts the importance of the Speco in relation to the origins of the Benedictine order and those of the papacy itself. The decoration of the chapel 
of St. Gregory, which we cannot discuss in detail here, ${ }^{6}$ marks the start of the second phase of the sanctuary with the construction of the large lower church (Figure 6).

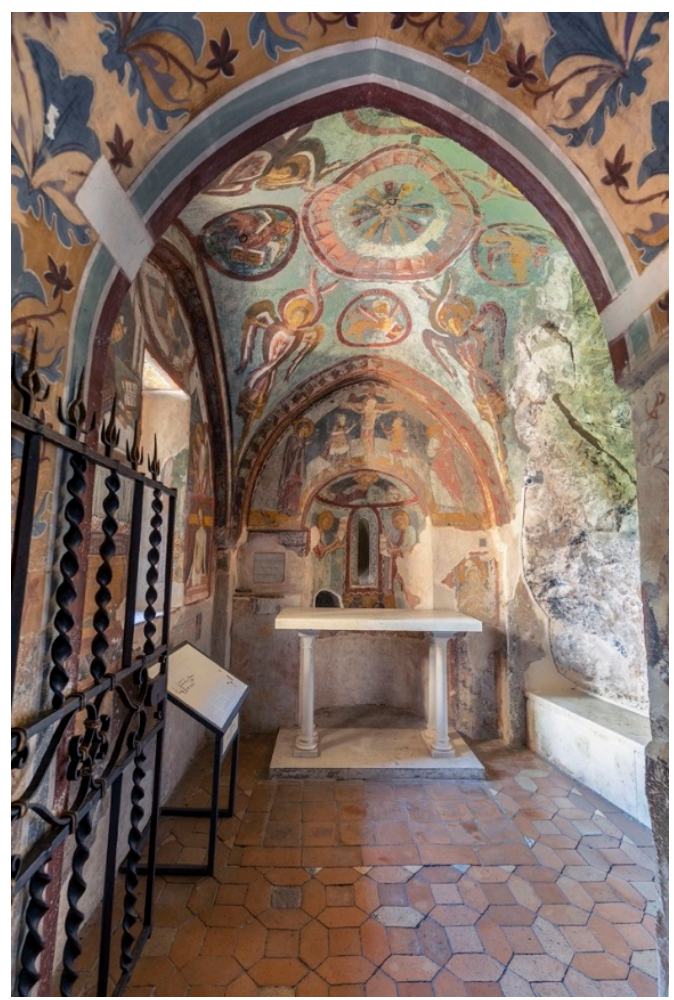

Figure 5. Sacro Speco, Subiaco (Italy), chapel of St. Gregory. Photo: Davide Giannetti.

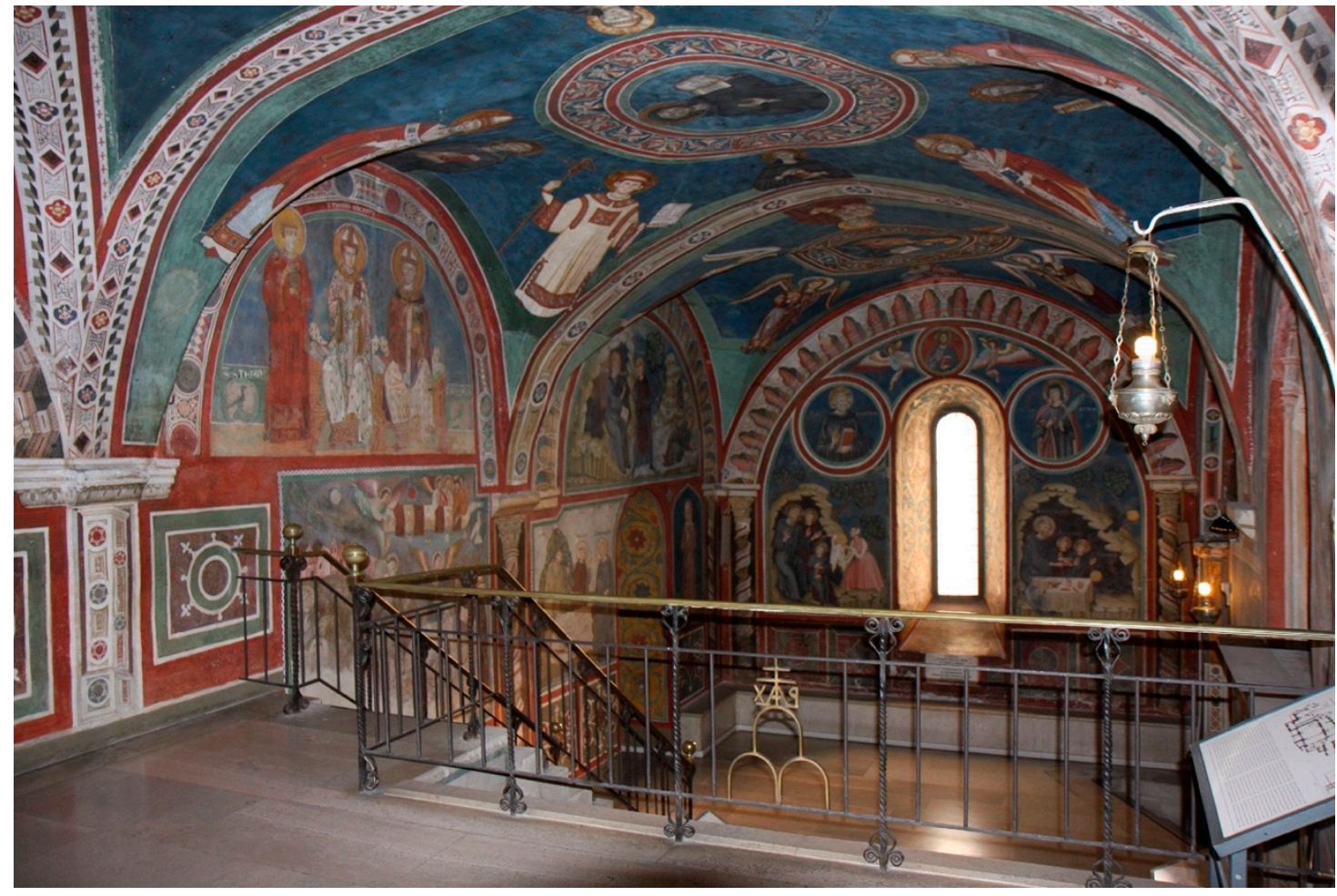

Figure 6. Sacro Speco, Subiaco (Italy), Lower Church. Photo: Roberta Cerone. 
The creation of this new liturgical space entailed the rationalization of the route followed by the faithful, fragmented between the chapel of the Virgin with the overlying chapel of St. Gregory, the room containing the Holy Stairs, and the landing hosting the fresco with the Bull of Innocent III (Figure 7). The creation of this large space, divided into three bays with a cross vault, made it possible to redesign the staircase in a more monumental form. The latter was also provided with a new roof; the entrance to the chapel of St. Gregory was rearranged and the residential block for the monks was built, grafted onto the sanctuary from the west.

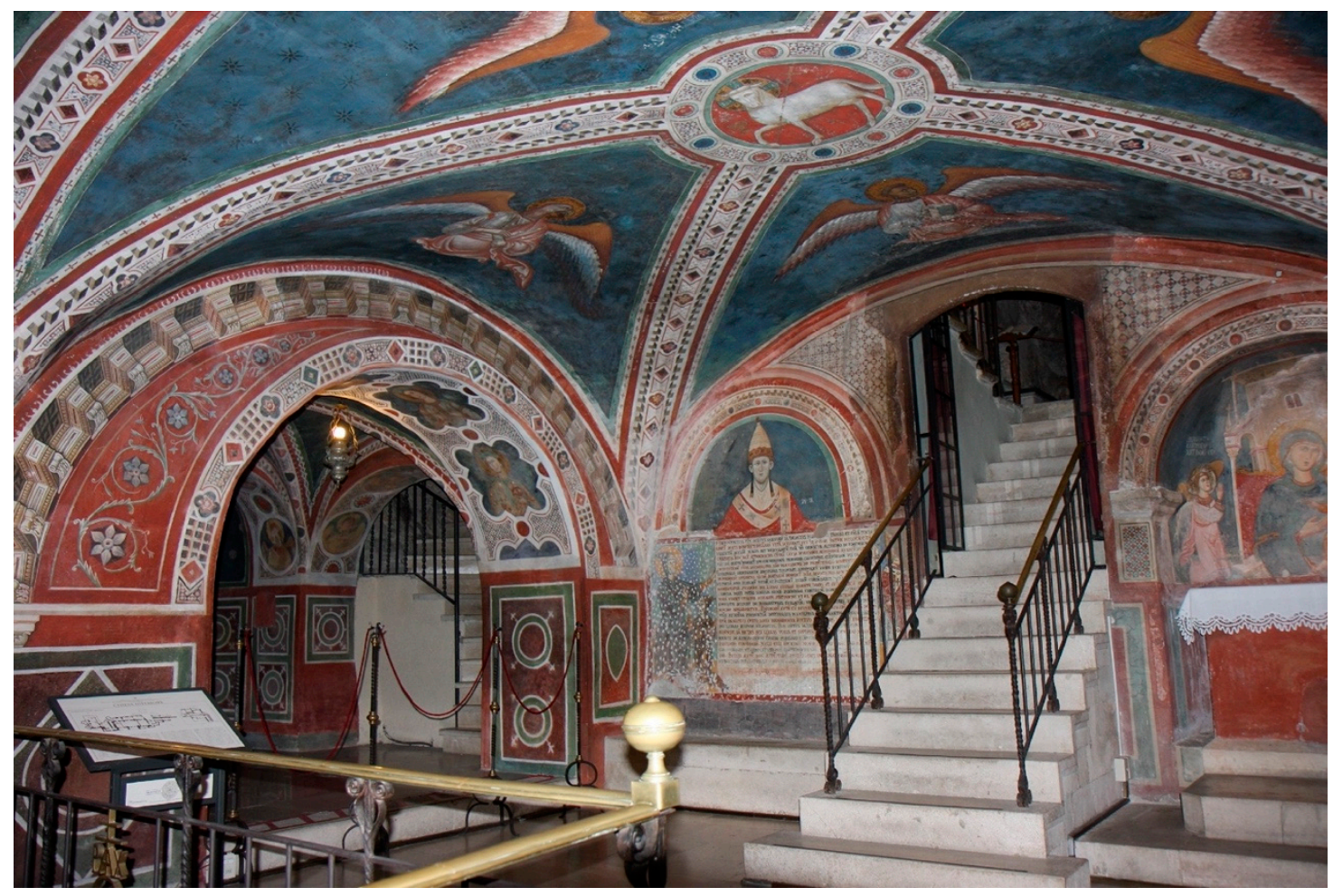

Figure 7. Sacro Speco, Subiaco (Italy), Lower Church. Landing hosting the fresco with the Bull of Innocent III. Photo: Roberta Cerone.

It is impossible to establish the exact date of the whole enterprise: given its imposing nature, construction must have taken several decades. Certainly, the external analysis of the walls, the architectural characteristics and the information provided by the chronicles suggest the hand of the two great abbots: Landus (1227-1243) and Enricus (1245-1273), also protagonists of the restructuring of Santa Scolastica (Cerone 2015, pp. 73-79). Moreover, the terminus ante quem for this construction phase is represented by the Stories of Benedict frescoed on the walls of the hall and in the cave between the end of the century and the very beginning of the next. ${ }^{8}$ This cycle was executed by a highly diverse workshop led by Magister Conxolus, who signs his name on the north wall beneath the Virgin and Child, and consists of a careful selection of scenes from the life of the saint, relating exclusively to his time at Subiaco and aimed at highlighting the presence of the cave, depicted in almost all of the episodes (Figure 8). 


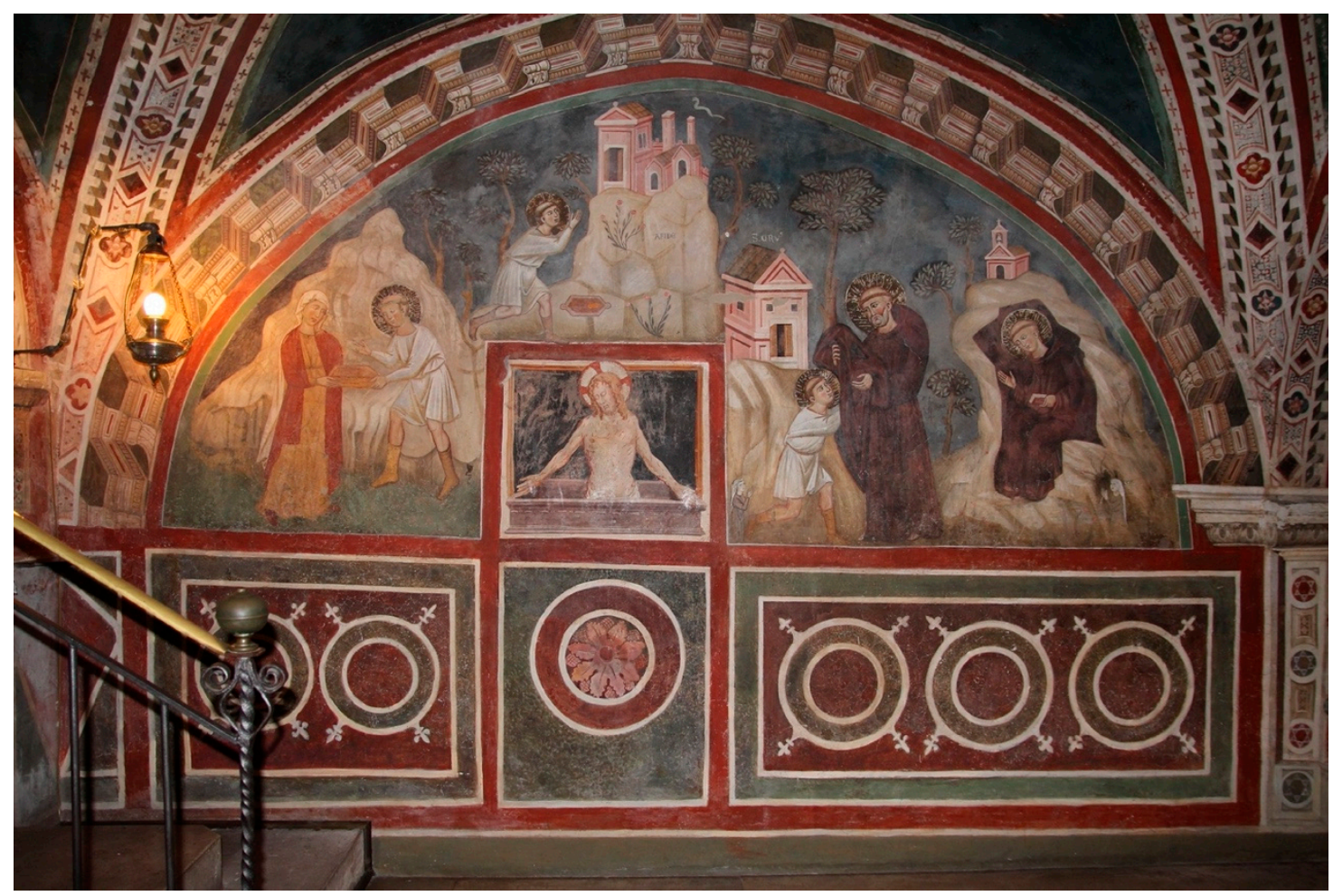

Figure 8. Sacro Speco, Subiaco (Italy), Lower Church. First episodes of the Life of St. Benedict. Photo: Roberta Cerone.

Obviously, we do not know which decorations were obliterated by Conxolus' new paintings, but we do know that he spared two pre-existing paintings: the Bull of Innocent and the lunette with Thomas Becket (Figure 1). Whilst the preservation of the former is explained by evident reasons of propaganda, ${ }^{9}$ the motivations underlying the choice to maintain the lunette that seems to abruptly and incongruously interrupt the narrative flow of the Vita Benedicti are less evident.

\section{The Fresco with Thomas Archiepiscopus}

The painting with Thomas Becket (Figure 1) decorates the top lunette on the western wall of the middle bay of the lower liturgical hall (Figure 9). On a blue background, it depicts a long throne carved with two steps on which sit Thomas Becket and St. Nicholas of Myra to his left; to the right of the English martyr stands the figure of St. Stephen. All three characters are blessing with their right hand while in their left they hold a book. Thomas and Nicholas are dressed in bishop's robes, with a mitre, pallium and cope, while Stephen wears his customary dalmatic. The figures are identified by tituli, but while that of Thomas archiepiscopus is located at the top, on the red frame of the archivolt, Sanctus Nicolaus and Sanctus Stefanus are written in different characters by the sides of the two saints and both are surmounted by the same coat of arms: a bird above a mountain with five peaks.

The fresco presents some formal and compositional inconsistencies: the faces have been repainted, in particular, that of Stephen (Figure 10), and there are evident changes to the shape of the halos and, in the case of the two bishops, the mitres, the collar and the position of the hand and book, repainted higher up (Figures 11 and 12); the figure of Stephen and, to a lesser extent, that of Nicholas, protrude from the blue background and invade the later "Cosmatesque" frame to which they are connected through a white line that also surrounds the coloured areas of the background. The coats of arms were added when the fresco was dry and have now lost their original colour and part of the black outline, but they may be contemporary with the original painting. ${ }^{10}$ 


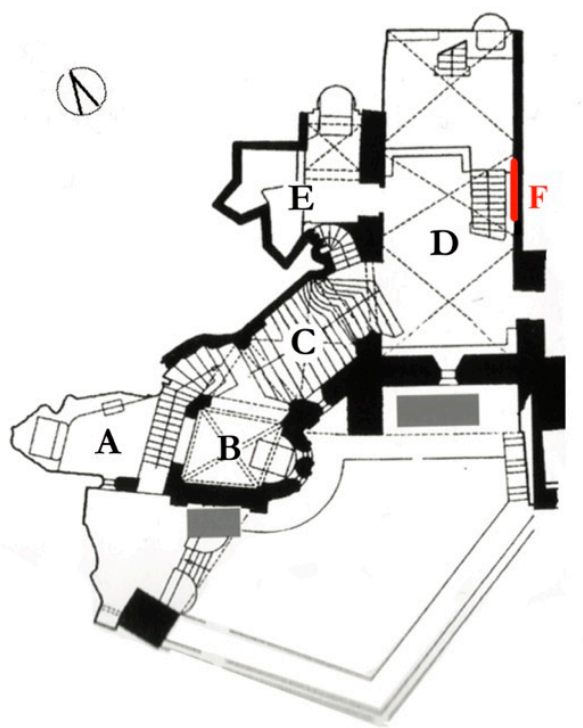
A. Cave "of the shepherds"
B. Chapel of the Virgin
C. Holy Stairs
D. Lower church
E. Benedict's cave
F. Lunette with St Thomas Becket

Figure 9. Sacro Speco, Subiaco (Italy), Plan of the Lower Levels. Photo: Roberta Cerone.

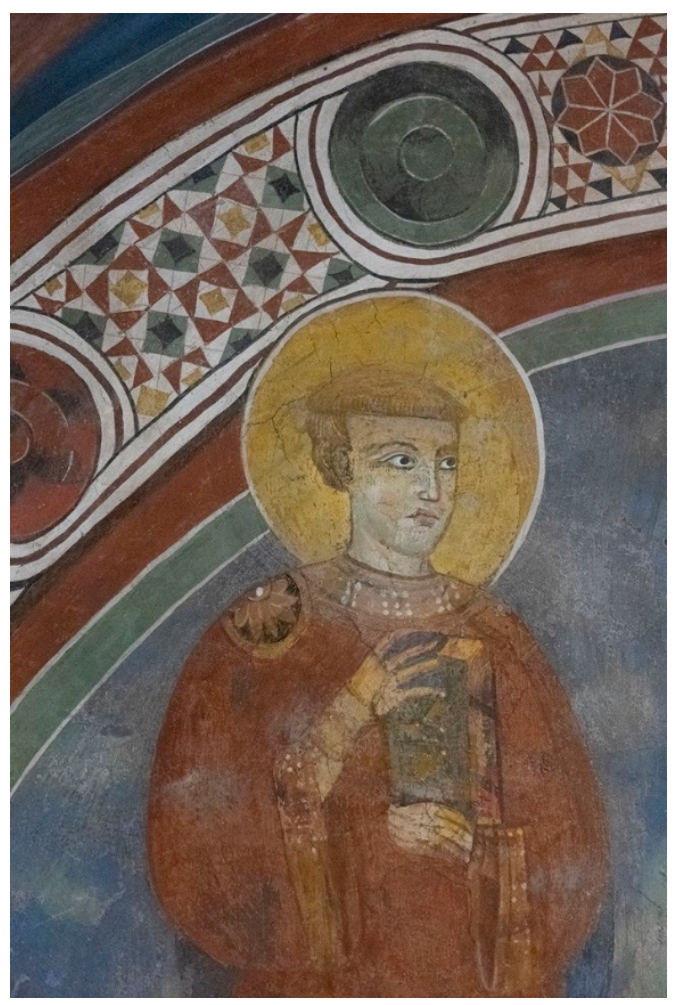

Figure 10. Sacro Speco, Subiaco (Italy), Lower Church. Fresco. Lunette, particular of St. Stephan. Photo: Davide Giannetti. 


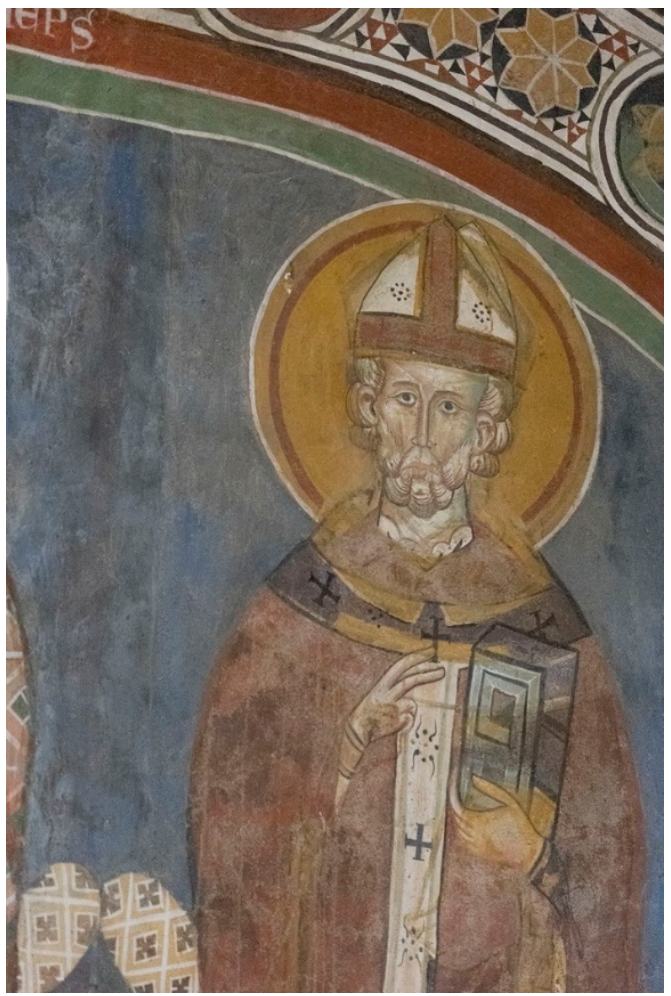

Figure 11. Sacro Speco, Subiaco (Italy), Lower Church. Fresco. Lunette, particular of St. Nicholas. Photo: Davide Giannetti.

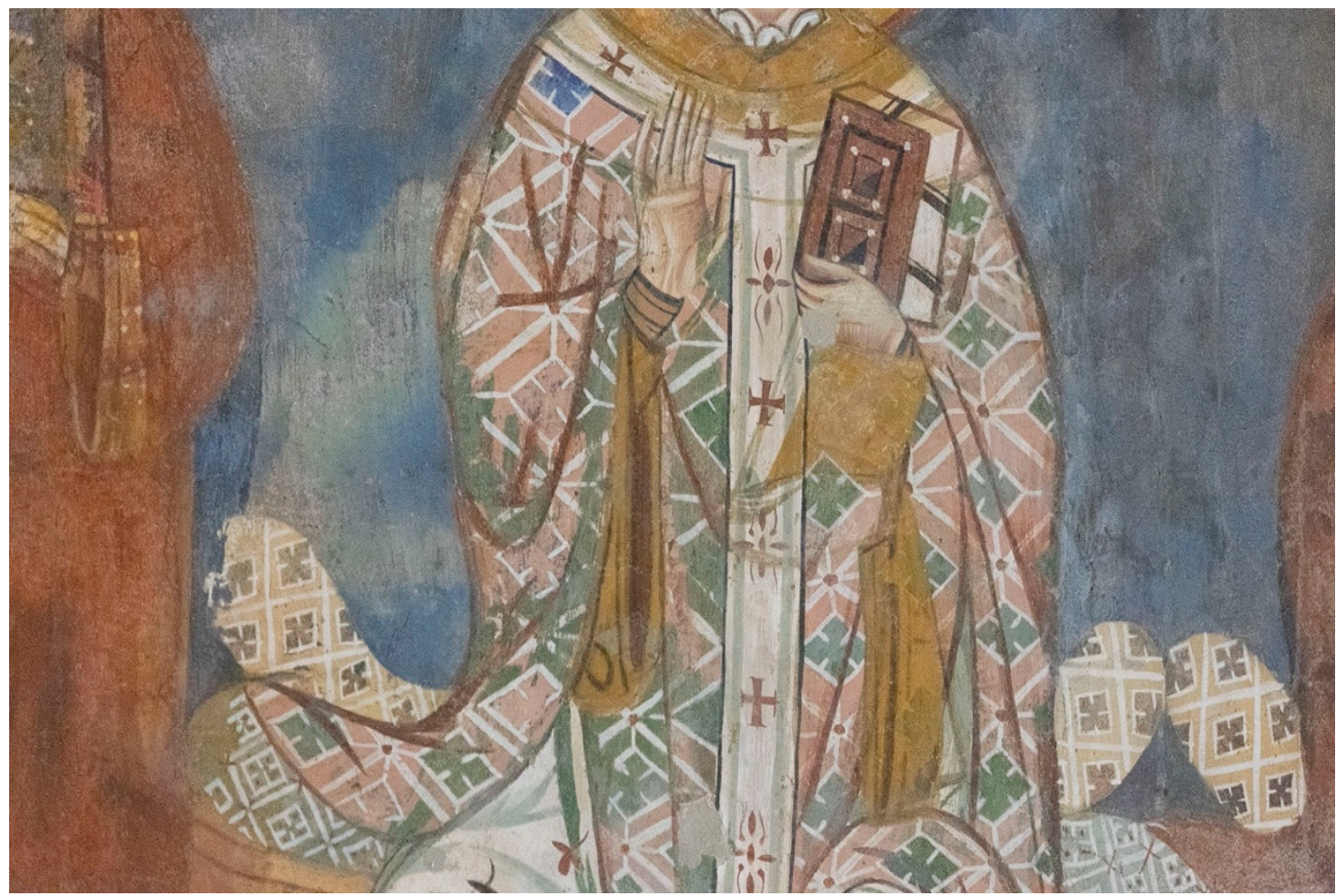

Figure 12. Sacro Speco, Subiaco (Italy), Lower Church. Fresco. Lunette, particular of St. Thomas. Photo: Davide Giannetti.

From a stylistic point of view, the panel presents some archaic features with respect to the surrounding scenes of Benedict, as already noted by Federico Hermanin, according 
to whom the painting "differs from its neighbours by Magister Conxolus and is a remnant of the previous decoration, a work, as I have already said, of a master contemporary with those of the chapel of St. Gregory". ${ }^{11}$ Hermanin's observation, supported by the evident superimposition of the plaster for the Funeral of St. Benedict beneath it, was reiterated in much subsequent criticism, with the addition of significant clarifications. Guglielmo Matthiae again compared the panel to the paintings in the chapel of St. Gregory but assigned them to a different hand "given the coarseness of the outlines, the rough materiality of the proportions and colour". ${ }^{12}$ Whilst Cristiani Testi has again connected the painting to the fresco campaign of the end of the century, Francesco Gandolfo and Serena Romano have both taken up Matthiae's hypothesis, though stressing that the painting was altered when it was incorporated into the new cycle with the Stories of Benedict (Cristiani Testi 1982, p. 132; Matthiae and Gandolfo 1988, p. 285; Romano 1992, p. 130).

The hypothesis of late repainting would explain the formal inconsistencies of the lunette and does not contradict the construction history of the lower church. The wall hosting the fresco may in fact have been preserved in the phase of the Abbots Lando and Enrico when the lower church was built; indeed, the triptych of saints is exactly aligned with the route taken by the Holy Stairs at the time of Innocent and it is, therefore, reasonable to suppose that it was on one of the retaining walls of the staircase, like the wall with the frescoed Bull, also repainted during the campaign of Magister Conxolus. This is confirmed by the discovery of a wall running obliquely with respect to the west wall during the renovation of the floor of the lower church in the early twentieth century; this wall followed the old course of the staircase and therefore ran from the right edge of the lunette to rejoin the lower section of the staircase, that which still exists today, closing the space towards the valley (Salvi 1953, p. 4). This sequence of phases is also supported by an examination of the external walls: the wall closing the lower church dates to a different and later time with respect to the small remnant of masonry belonging to the "Innocentian" Holy Stairs, adjacent to and contemporary with the chapel of the Virgin ( Righetti Tosti-Croce 1982, p. 81).

Due to the subsequent modernization, the reading of the fresco with Thomas Becket does not allow the identification of a precise chronology beyond a generic attribution to the first half of the 13th century based on the similarities with the paintings in the chapel of St. Gregory, now firmly dated to 1228 (Ladner 1970, pp. 105-11). However, the date can be narrowed down to the first quarter of the century if we trust the interpretation of the coat of arms (Figure 13), assigned by a long critical tradition to the Abbot Iohannes VIII (1217-1227), prior of the Speco at the time of Innocent III. He is a figure of whom little is known and whose family origin is divided between Tagliacozzo, in nearby Marsica (now Abruzzo), and a less identifiable Palombaro. ${ }^{13}$ This information was first provided by the scholar Vincenzo Bini, who in his Memorie storiche della S. Grotta e del monastero di San Benedetto sopra Subiaco of 1840 recalls having tracked down documents in the archives of Subiaco relating to the Abbot Iohannes, who "in addition to having had this church painted, loved to affix his family crest consisting of a mountain with a bird sitting on top of it to the paintings". ${ }^{14}$ Unfortunately, it has proved impossible to find the sources cited by Bini, but at the present state of knowledge, there is no reason to doubt his account, both because nineteenth-century scholars often had access to materials that are now lost, and because the identification of the coat of arms is in keeping with the stylistic and historical context of the fresco. 


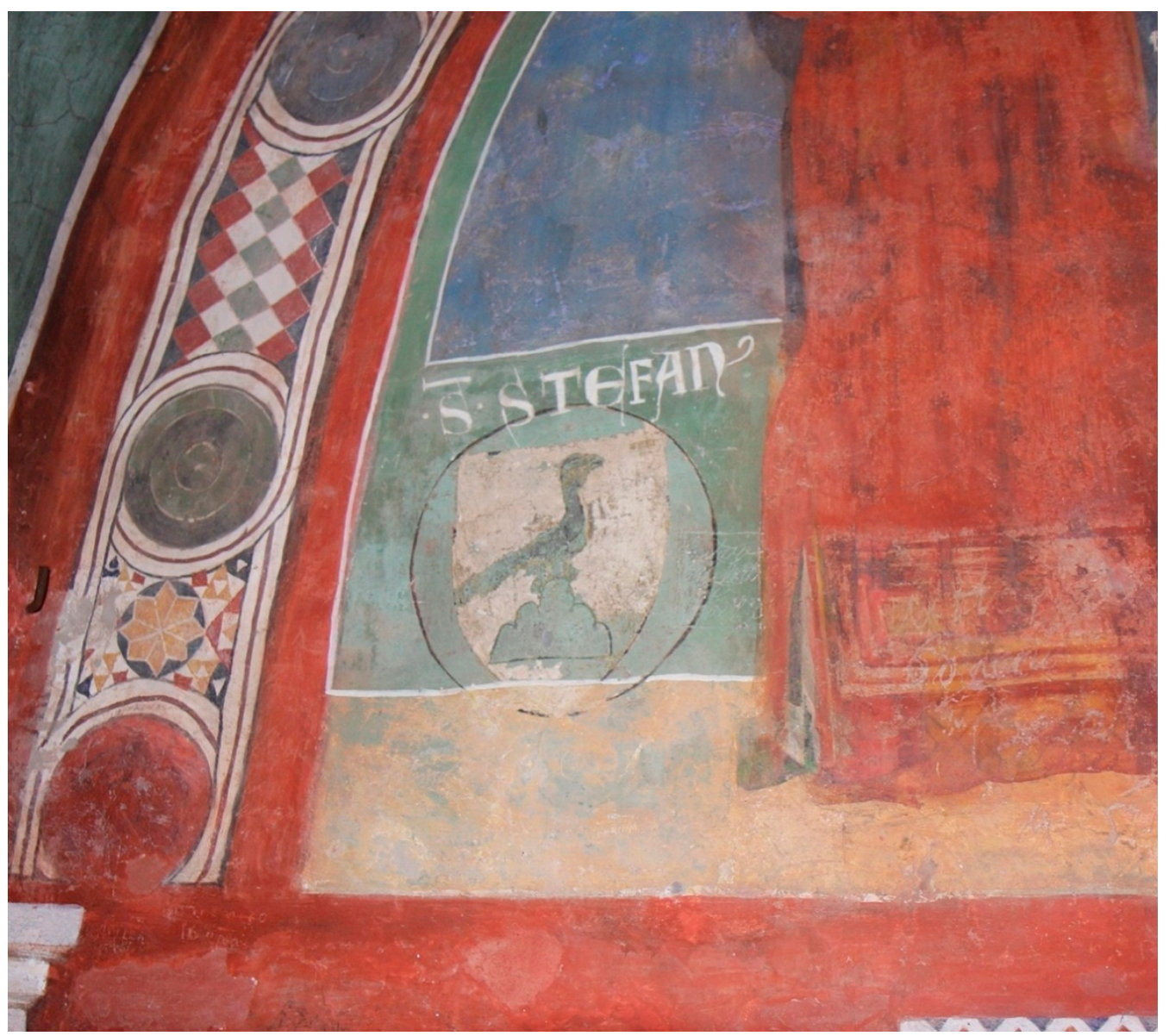

Figure 13. Sacro Speco, Subiaco (Italy), Lower Church. Fresco. Lunette, particular of the coat of arms. Photo: Davide Giannetti.

It is therefore important to note that both frescoes preserved in the new decoration were linked to the Prior/Abbot Iohannes, though they are representative of two different times in his life. The painting with the privilege of Innocent does not show him, although the text of the Bull was addressed to him as prior of the community. As indicated by the coats of arms, however, he commissioned the lunette, but at the time of Honorius III, when he had already become abbot. Furthermore, the display of his heraldic emblem in the sanctuary is a strong act of self-celebration, which can more logically be connected to the political power of an abbot than to the status of a prior; as proof of this suffice it to remember that, as prior, Iohannes had been "forgotten" in the bull of Innocent in favour of the Abbot Romanus, though the latter was not the intended recipient of the praises and favours of the pontiff.

The dating of the fresco to the time of Honorius III is easily contextualized, if we consider the interest shown by the Pope in the monasteries of Subiaco and his efforts to encourage the cult of some saints, certainly including Thomas Becket, albeit not exclusively. The provisions issued by Honorius III to benefit the site are in continuity with those of his illustrious predecessor. Among these, in relation to the Speco, it is worth citing the document of 3 February 1217 confirming the donation of Innocent III, namely the annual income from the Castrum Porciani, recalled in the fresco with the Bull (Federici 1904, p. 52, n. cclxii). This time, financial support was accompanied by the continuation of the monumentalization process at the site with the erection of the chapel of St. Gregory above the chapel of the Virgin.

It is important to remember that Honorius III encouraged the spread of the worship of Thomas Becket (Figure 14). Honorius maintained good relations with Canterbury: here he had rehabilitated Archbishop Stephen Langton-exiled in 1215 on the orders of Innocent 
III-and granted indulgences to pilgrims who visited the saint's tomb in 1220, on the occasion of the jubilee organized by Langton to mark the translation of his body. There must already have been some relics of Thomas Becket in Rome, but new ones clearly arrived during the papacy of Honorius, perhaps including the famous tunicle kept in the basilica of Santa Maria Maggiore in Rome. ${ }^{15}$ In 1217, the altar of the crypt of St.s Boniface and Alexis, hosting a relic of the English saint, was reconsecrated. Subsequently, other relics were brought by Stephen Langton, attested in Rome in the autumn of 1220, when we know that he delivered a sermon on the archbishop of Canterbury at the pope's request (Holdsworth 2004). Another individual who may have been responsible for the arrival of sacred relics was Cardinal Guala Bicchieri, papal legate in England from 1216 to 1218, who on his return to Italy brought the remains of Thomas's sword of martyrdom to Vercelli (Cipollaro and Decker 2013, p. 117). He probably also donated something similar to the Roman church of San Martino ai Monti, of which he was cardinal titular between 1211 and 1227 and where he also commissioned the decoration of the apse in the oratory of St. Sylvester with a procession of saints including Thomas of Canterbury (Riccioni and Querijo 2012).

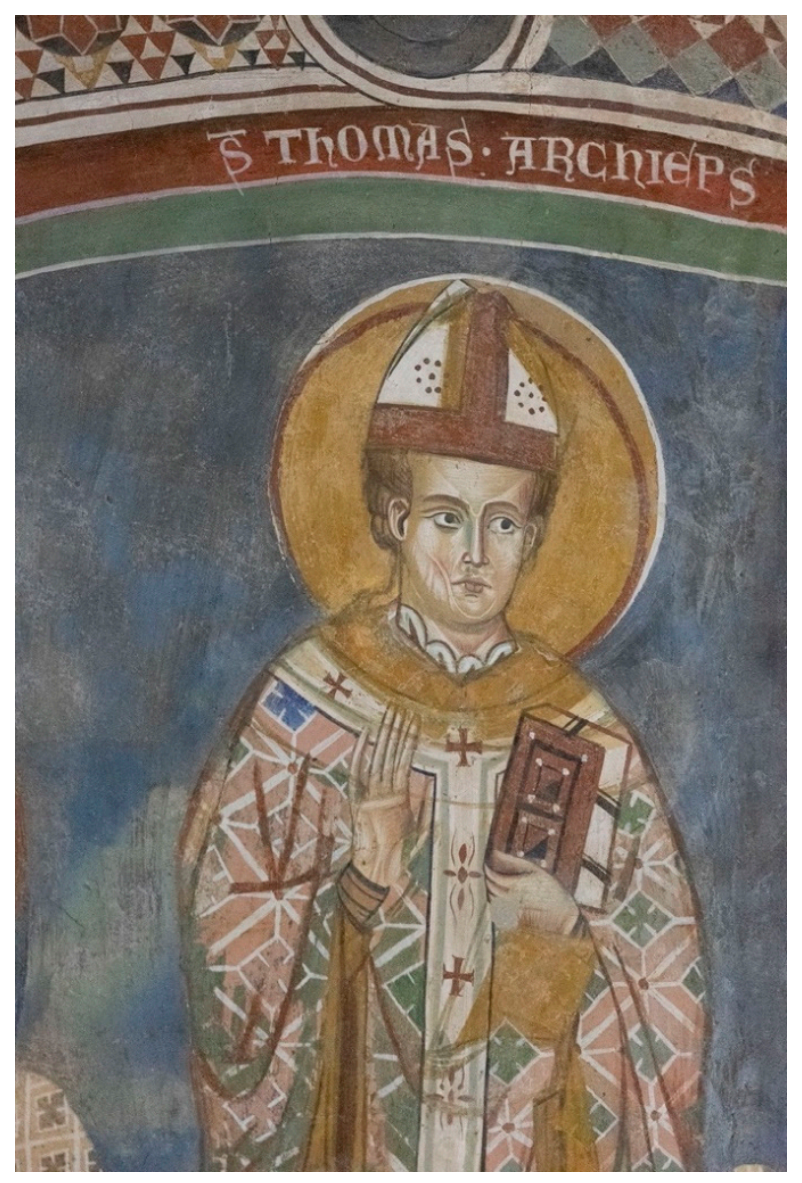

Figure 14. Sacro Speco, Subiaco (Italy), Lower Church. Fresco. Lunette, particular of St. Thomas Becket. Photo: Davide Giannetti.

The choice to represent the figure of the English archbishop at the Sacro Speco can therefore be linked, in general, to the climate of the exaltation of this new martyr of the church, who lost his life in a dispute with temporal power, at a site that had been a direct emanation of the Roman Church since its earliest history. This link between the monasteries and papal Rome was both political and spiritual in nature, and was also expressed through the arts: the painting with the Bull of Innocent III should be read in this light, as should the "Cosmatesque" cloister by Magister Iacobus in the monastery of Santa Scolastica. The 
cloister, whose first phase dates to the years of Innocent III, gave visual expression to Rome's authority in the territories of the Patrimonium Petri through its classical character (Cerone 2015, pp. 66-73). Similarly, going slightly beyond the years of Honorius III, the decoration of the chapel of St. Gregory during the papacy of Gregory IX (1227-1241) came to constitute an explicit manifesto of the power of the pope, with the figure of the pontiff presenting himself as the new Gregory the Great. ${ }^{16}$

In light of these considerations, the presence of Thomas Becket at the Speco takes on extraordinary importance, though the monasteries never hosted his relics nor a specific veneration of the saint. In this context, however, it should be remembered that Subiaco had ties to the territories of the Campagna in Southern Latium, to which it was connected through the route across the Altipiani di Arcinazzo. In this area, the cult of Thomas Becket had been spreading since the time of Alexander III (1159-1181), as demonstrated above all by the extraordinary paintings in the oratory of Anagni and then a whole series of buildings and decorative programmes honouring the English saint throughout the 13th century, such as the frescoes of Santa Maria del Reggimento at Casamari (Quattrocchi 2018; Farina 1990, p. 134).

In the lunette of the Speco, the new martyr of Canterbury is deliberately depicted with the proto-martyr Stephen, a figure particularly venerated in Rome, to the extent of becoming emblematic of the Church itself. Honorius III, even when he was "only" Cencio Camerarius, had devoted himself to the basilica of San Lorenzo fuori le mura at Verano, where Stephen's body rested in a double tomb with that of the martyr Lorenzo. ${ }^{17}$ Less straightforward is the juxtaposition of Thomas and Nicholas of Myra, who shares the Englishman's wooden chair and appearance, in a sort of telling repetition of the same figure of an archbishop, one young and the other of advanced age. Nicholas and the saint from Canterbury share not only their rank within the church, but also the role of protecting the drowned and their nature as thaumaturgic saints. ${ }^{18}$ Their tombs are privileged places for miracles, making their respective burial sites important destinations for pilgrimage. In this sense we can also associate the two with the figure of Stephen; after all, it was precisely the increase in the number of the faithful travelling to the tomb at Verano that prompted Honorius III to renovate the sacred area and later to enlarge the basilica. In this context, we should not forget where we are: Benedict shares with these three figures their exceptional fame, which gave rise to the pilgrimage to his cave, the Sacro Speco, a place where miracles occurred, as was the case with the tombs of Stephen, Nicholas and Thomas Becket.

The association of saints ostensibly so different from each other thus proves to be a wise choice replete with meanings relating to the historical setting and context of Subiaco. The connection of the three characters to the figure of Benedict of Norcia takes shape through the common thread of pilgrimage to a place where Benedict still works his miracles. I, therefore, believe that the preservation of the lunette in the renovation and decoration project of the end of the century can be explained by the desire to keep alive the conceptual connection binding Benedict to old and new hagiographic figures, in reference to the thaumaturgical significance of this devotional place. Proof of this may come from a consideration of the episode in the cycle of Benedict that was chosen to be depicted immediately below the triptych of saints: his Funeral (Figures 15 and 16). 


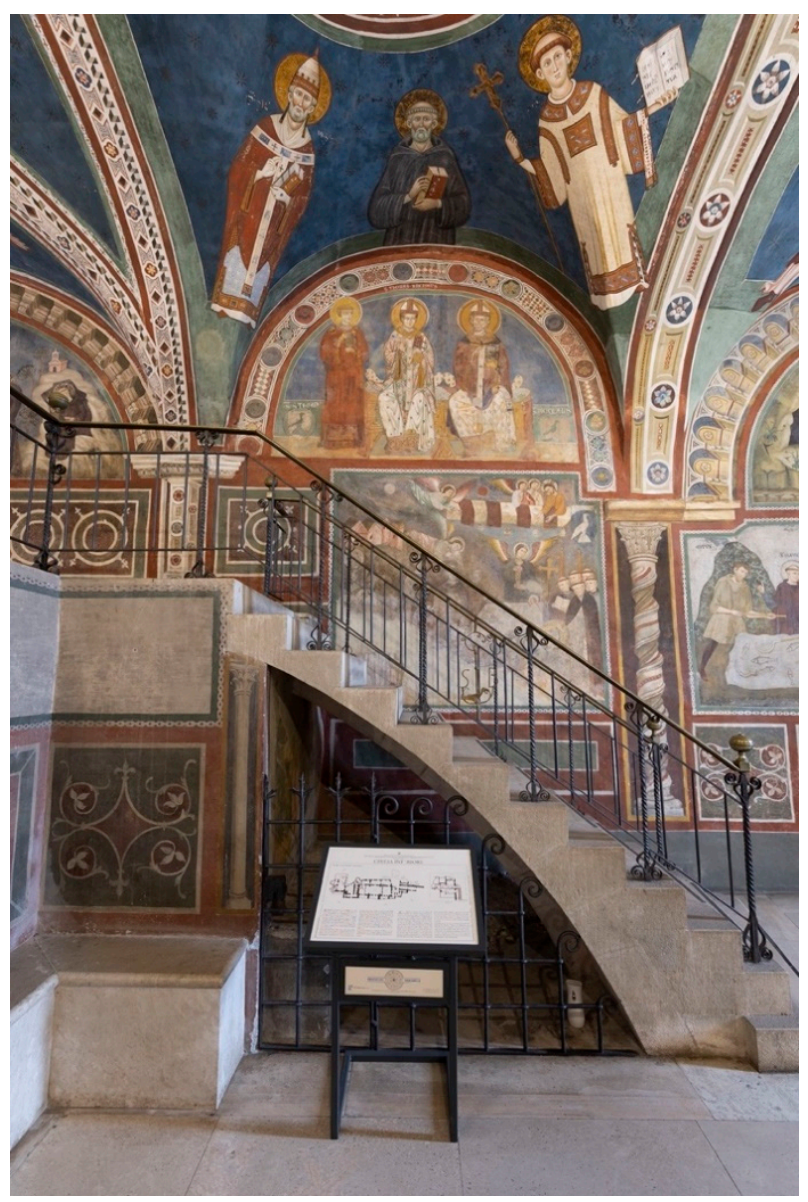

Figure 15. Sacro Speco, Subiaco (Italy), Lower Church. Frescoes. Lunette with St. Stephan, St. Thomas Becket, St. Nicholas and Funeral of St. Benedict. Photo: Davide Giannetti.

Like the lunette with Becket, the presence of this scene is unexpected: it is the only episode in the painted biography that takes place not at Subiaco but at Montecassino. Furthermore, like the lunette above, the panel interrupts the chronological sequence of the story, positioned as it is between the saint's first miracles at Affile and his vestition by Romanus, in the first bay, and the miracles at Subiaco in the third bay (Miracle of the Goth, Rescue of Placidus). In this case, too, the choice is far from random. According to the Dialogues of Gregory the Great, it was precisely at the moment of Benedict's burial that the first miracles began to occur at the cave. ${ }^{19}$ The representation therefore only serves to enhance the prodigious quality of the cave and substantiate the pilgrimage to it. The moment of the saint's funeral is not just a link with the lunette, but is the key to reading the entire cycle of Benedict: in the wall paintings of Conxolus the glorification of the cave bounces from wall to wall, so much so that in front, though at the time the current entrance to the cave did not yet exist, there was already the upper window that allowed pilgrims to gaze at the holy place as they climbed the staircase and to see, right next to the window, the fresco of St. Benedict in the painted cave intent on pointing out to the viewer the real cave visible through the opening (Figure 17). 


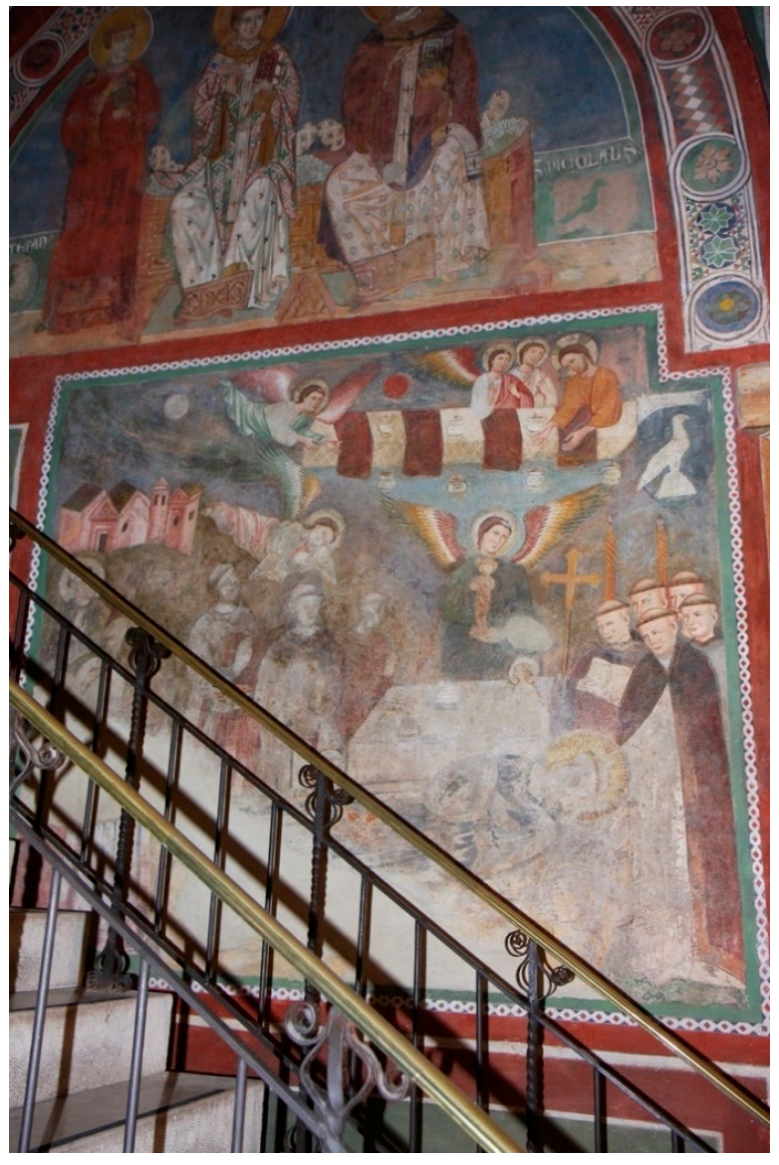

Figure 16. Sacro Speco, Subiaco (Italy), Lower Church. Fresco. Funeral of St. Benedict. Photo: Davide Giannetti.

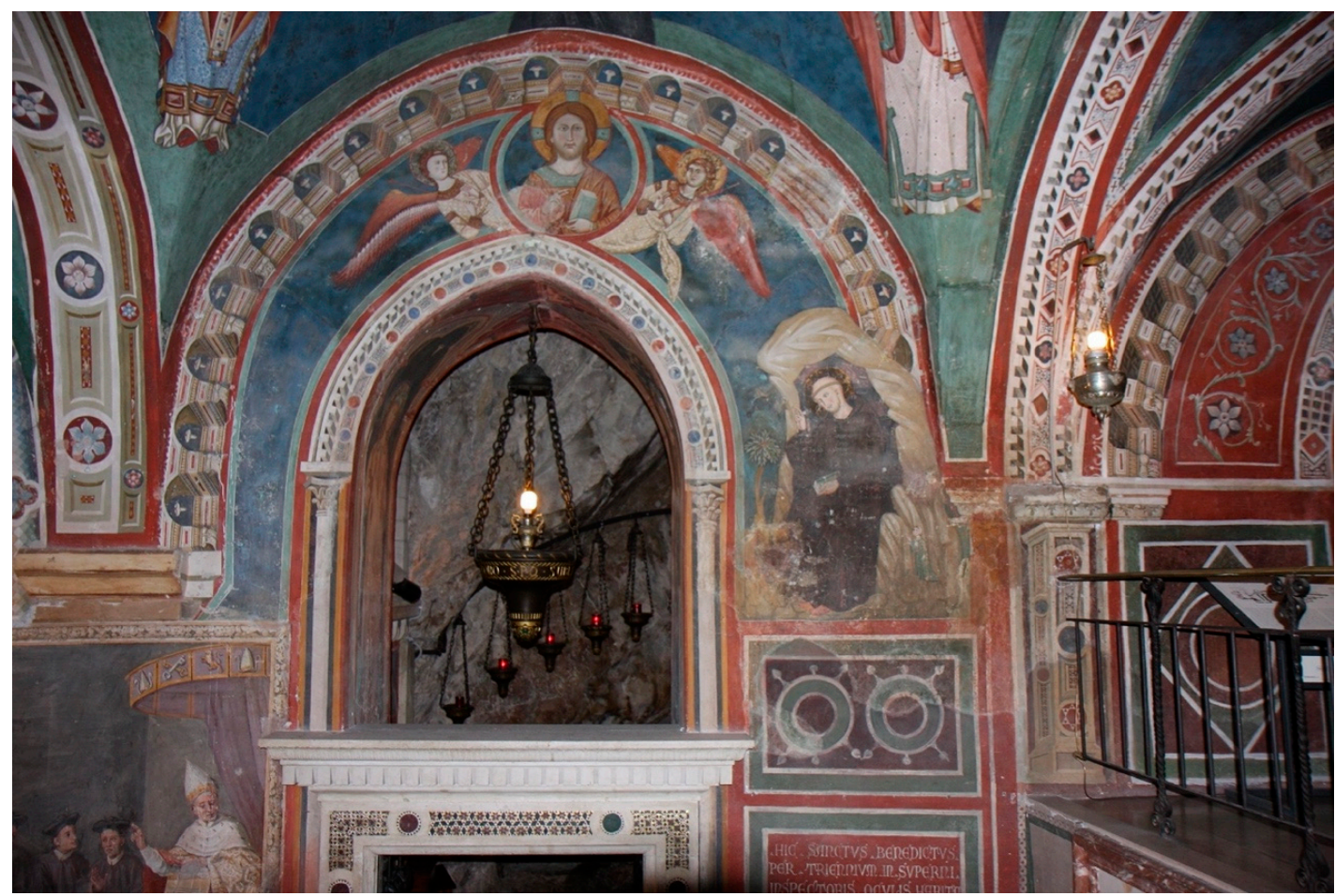

Figure 17. Sacro Speco, Subiaco (Italy), Lower Church. Fresco. St. Benedict pointing out the cave. Photo: Davide Giannetti. 
From the 14th century onwards, there was a documented custom of burying abbots in this area of the sanctuary, in front of the Funeral scene and "ad corpus" with respect to the cave. ${ }^{20}$ It cannot be ruled out that this custom already existed earlier and therefore contributed to the iconographical decision to place the Funeral at this point. Nor can we fail to consider that the presence of Abbot Giovanni's coats of arms might indicate that he himself was buried in this area. This is just a suggestion, of course, for which there is no documentary evidence, but the heraldic insistence in the lunette with Becket would seem to point in this direction.

In any case, the problem of the presence or otherwise of the burials of the abbots in the area does not alter the meaning that the fresco holds in the "old" and new decoration. The lunette with Stephen, Thomas Becket and Nicholas was a cornerstone of the original decoration of the Speco alongside the fresco showing the Bull of Innocent III. The two paintings celebrated the importance of Benedict's cave, a place of miracles and a destination for pilgrimage, and at the same time of the sanctuary and the monastic community that guarded it, as well as the special relationship that tied the place to the Roman popes. It is therefore unsurprising that these two paintings were updated in the decoration of the new lower church that led into the cave of Benedict and that they were inextricably linked to the hagiographic cycle that accompanied the faithful along their devotional path through the life and miracles of the founder of Subiaco.

Funding: This research received no external funding.

Institutional Review Board Statement: Not applicable.

Informed Consent Statement: Not applicable.

Conflicts of Interest: The authors declare no conflict of interest.

\section{Notes}

1 (Gregorius Magnus 1847, col. 128): “Benedictus plus appetens mala mundi perpeti quam laudes, et plus pro Deo laboribus fatigari quam vitae hujus favoribus extolli, nutricem suam occulte fugiens, deserti loci secessum petiit cui Sublacus vocabulum est, qui ab Romana urbe quadraginta fere millibus distans, frigidas atque perspicuas emanat aquas".

2 In general on the construction history of the Sacro Speco see (Giovannoni 1904, pp. 373-403; Righetti Tosti-Croce 1982).

3 This information comes from sales document, dated 17 July 1200, in (Federici 1904, p. 50, no. ccxxxiiii).

4 In general on the pope's policy in the Lazio area, cf. (Caciorgna 2003; Carocci 2003).

5 "Innocentius episcopus servus servorum Dei. Dilecti fili Ioh(ann)i priori et fratribus iuxta Specum beati benedicti regularem vitam servantibus", thus begins the Bull, see (De Prosperis 2008, pp. 20-21).

6 On the iconography of the cycle, see (Frugoni 1993, pp. 269-75).

7 (Righetti Tosti-Croce 1982, pp. 84, 86). Specifically on the structures of the monastery see (Cerone 2016, p. 118).

8 The cycle of the Stories of Benedict was executed at around the same time, but the problem of identifying one or more workshops active at the site and the role of Magister Conxolus remains controversial, as does the rapport with the contemporary painting of Assisi and Rome. For the formal and chronological contextualization of the Stories of Benedict cf. most recently: (Belting 1977, p. 160; Cristiani Testi 1982, pp. 120-32; Cristiani Testi 1983, pp. 403-7; Bellosi 1985, pp. 130-45; Matthiae and Gandolfo 1988, pp. 328, 357-59; Romano 1992, pp. 131-33).

9 The fresco with the Bull was also repainted to adapt it to the new decoration. The large bust of Innocent III was added in the lunette above, and the older versions of the pontiff himself, of Romanus and of Benedict, were deleted, replaced by a new image of Benedict, see (Cristiani Testi 1983).

10 More complex is the problem of the third coat of arms, coloured blue and painted a little lower down, above the scene of the funeral of St. Benedict, and similar to the other two. This third coat of arms is not visible in the mid-19th-century engravings (Renier 1855), nor in the photos by Giovanni Gargiolli of 1902-1903 (Rome, Istituto Centrale per il Catalogo e la Documentazione, GFN, E000349), which show the fresco in a precarious condition. It therefore seems plausible that was brought to light by restoration work, following the work by G. Giovannoni in which the Holy Stairs were moved away from the wall. It is not easy to contextualize the emblem, but certainly seems to imitate those of the lunette and is therefore later.

11 Hermanin (1904, p. 475): "si discosta dalle vicine di Magister Conxolus ed è un avanzo della decorazione anteriore, opera, come ho già detto di un maestro contemporaneo di quelli della cappella di San Gregorio".

12 Matthiae and Gandolfo (1988, p. 115): "per la pesantezza dello squadro, per la materialità greve delle proporzioni e del colore". 
According to Salvi (1955, p. 28), the prior of the Speco was not the monk from Tagliacozzo, but another Giovanni de Palombaro whose existence he verified in the Vatican Archive (Registri Vaticani).

14 (Bini 1840, pp. 32-33; Gori 1855, p. 46; Barbier de Montault 1858, p. 357). The latter, while making evident reference to Bini's text, underlines the presence of two coats of arms and specifies that they were " $\mathrm{d}$ 'argent à un oiseau de sable sur une montagne de sinople" (silver with a black bird on a green mountain). The association is later taken up by (Hermanin 1904, p. 464), and much subsequent criticism.

15 About the tunicle see (Nilgen 1995).

16 The apse of the chapel even contained a reproduction in smaller form of the decoration of the Vatican apse with the figures of the apostles Peter and Paul, see (Frugoni 1993, p. 269) and following.

17 On the cult of St. Lawrence in Rome, see (Nuzzo 2020). For a summary of Honorius III's interventions in San Lorenzo fuori le mura, see (Mondini 2001, pp. 209-14).

18 In general on the cult of St. Thomas, see (Foreville 1981; Webster 2016); on the cult and iconography of St. Nicholas of Myra see (Ševčenko and Falla Castelfranchi 1997), with preceding bibliography.

19 (Gregorius Magnus 1847, col. 202): "in eo specu in quo prius Sublacus habitavit, nunc usque si petentium fides exigat, miraculis coruscat". It is important to remark that the biography of St. Benedict ends in the next chapter (nr. XXXVIII) where Gregorius talks about the miracle post mortem happened in Subiaco ("De insana muliere in ejus specu sanata").

This is the tomb of the Abbot Iohannes IX (1344-1348), found at the end of the sixteenth century, see (Mirzio [1628] 2013, p. 607).

\section{References}

Barbier de Montault, Xavier. 1858. Subiaco, Les fresques du Sacro Speco. Annales Archéologiques 18: 350-59.

Bellosi, Luciano. 1985. La pecora di Giotto. Torino: Einaudi.

Belting, Hans. 1977. Die Oberkirche von San Francesco in Assisi. Berlin: Mann.

Bini, Vincenzo. 1840. Memorie storiche della S. Grotta della chiesa e del monastero di san benedetto sopra Subiaco. Roma: Tipografie delle Belle Arti.

Caciorgna, Maria Teresa. 2003. La politica di Innocenzo III nel Lazio. In Innocenzo III. Urbs et orbis. Atti del Convegno internazionale, a cura di A. Sommerlechner (Roma, 9-15 settembre 1998), 2 vols. Roma: Istituto storico italiano per il Medioevo, vol. I, pp. 691-725.

Carocci, Sandro. 2003. «Patrimonium Beati Petri» e «fidelitas». Continuità e innovazione nella concezione innocenziana dei domini pontifici. In Innocenzo III. Urbs et orbis. Atti del Convegno internazionale, a cura di A. Sommerlechner (Roma, 9-15 settembre 1998), 2 vols. Roma: Istituto storico italiano per il Medioevo, vol. I, pp. 668-89.

Carucci, Arturo, and Raffaello Morghen, eds. 1991. Chronicon sublacense (aa. 593-1369). Roma: Istituto poligrafico e Zecca dello Stato.

Cerone, Roberta. 2015. La regola e il monastero. Arte e architettura in Santa Scolastica a Subiaco. Roma: Campisano editore.

Cerone, Roberta. 2016. Architettura e decorazione fino al XIV secolo. Bollettino d'Arte 101: 118-23.

Cipollaro, Costanza, and Veronica Decker. 2013. Shaping a Saint's Identity. The Imagery of Thomas Becket in Medieval Italy. In Medieval Art, Architecture \& Archaeology at Canterbury. Edited by Alixe Bovey. Leeds: Maney Publisher, pp. 116-38.

Cristiani Testi, Laura. 1982. Gli affreschi del Sacro Speco. In I Monasteri benedettini di Subiaco. Edited by Carlo Giumelli. Milano: Amilcare Pizzi, pp. 95-202.

Cristiani Testi, Laura. 1983. Il maestro del busto di Innocenzo III e i collaboratori. In Roma anno 1300. Atti della IV settimana di studi di storia dell'arte medievale dell’Università di Roma «La Sapienza». Edited by Angiola Maria Romanini. Roma: L' Erma di Bretschneider, pp. 403-11.

De Prosperis, Annarita. 2008. Innocenzo III e i monasteri di Subiaco. Latium 25: 3-30.

Farina, Federico. 1990. L'abbazia di Casamari nella storia dell'architettura e della spiritualità cistercense. Frosinone: ed. Casamari.

Federici, Vincenzo. 1904. La biblioteca e l'archivio. In I monasteri di Subiaco. Roma: Ministero della Pubblica Istruzione, vol. II.

Fiore Cavaliere, Maria Grazia. 1994. Monachesimo prebenedettino e benedettino: Note di topografia monastica. In Sublaqueum-Subiaco. Tra Nerone S. Benedetto. Edited by Maria Grazia Cavaliere. Roma: Quattro D Editrice, pp. 13-24.

Foreville, Raymonde. 1981. Thomas Becket dans la tradition historique et hagiographique. London: Variorum Repr.

Frugoni, Chiara. 1993. Francesco e l'invenzione delle stimmate. Una storia per parole e immagini fino a Bonaventura e Giotto. Torino: Einaudi.

Giovannoni, Gustavo. 1904. L'architettura dei monasteri sublacensi. In I monasteri di Subiaco. Roma: Ministero della Pubblica Istruzione, vol. I, pp. 263-402.

Gori, Fabio. 1855. Viaggio pittorico antiquario da Roma a Tivoli e Subiaco. Roma: Tipografia delle Belle Arti.

Gregorius Magnus. 1847. Vita S. Benedicti (Ex libro II Dialogorum S. Gregorii Magni excerpta). In Patrologiae cursus completus. Series prima. Edited by Jacques-Paul Migne. LXVI. Paris: Migne, cols. 125-204.

Holdsworth, Christopher. 2004. 'Stephen Langton'. In Oxford Dictionary of National Biography. Edited by Henry Colin Gray Matthew and Brian Harrison. XXXII. Oxford: Oxford University Press, pp. 516-21.

Hermanin, Federico. 1904. Notizie storiche dell'abbazia durante il Medioevo. In I monasteri di Subiaco. Roma: Ministero della Pubblica Istruzione, vol. I.

Israel, Uwe. 2004. Der Papst und die Urkunde an der Wand. Innozenz III (1198-1216). Subiaco, in Quellen und Forschungen aus italienischen Archiven und Bibliotheken 84: 69-102. 
Ladner, Gerhart. 1970. Die Papstbildnisse des Altertums und des Mittelalters, Band II., von Innozezn II. Zu Benedikt XI. Città del Vaticano: PIAC.

Matthiae, Guglielmo, and Francesco Gandolfo. 1988. Pittura romana del Medioevo, II, Secoli XI-XIV. Roma: Fratelli Palombi Editori.

Matthiae, Guglielmo, and Maria Andaloro. 1987. Pittura romana del Medioevo, I, Secoli IV-X. Roma: Fratelli Palombi Editori.

Mirzio, Cherubino. 2013. Chronicon sublacense (1628-1630). Edited by Luchina Branciani. 2 vols. Subiaco: Tipografia editrice Santa Scolastica. First published 1628.

Mondini, Daniela. 2001. Le 'tombe' dei martiri nelle basiliche di San Lorenzo fuori le mura e di San Sebastiano sull'Appia (secolo XIII). Mededelingen van het Nederlands Instituut te Rome 59: 208-29.

Nilgen, Ursula. 1995. La 'tunicella' di Tommaso Becket in S. Maria Maggiore a Roma. Culto e arte intorno a un santo politico. Arte Medievale 9: 105-20.

Nuzzo, Donatella. 2020. Le reliquie di Santo Stefano da Gerusalemme a Roma: Possibili percorsi e i luoghi di culto. In Legite, tenete, in corde habete. Miscellanea in onore di Giuseppe Cuscito. Edited by Fabrizio Bisconti, Giovannella Cresci Marrone and Fulvia Mainardis. Trieste: Editreg, pp. 315-24.

Pani Ermini, Letizia. 1981. Subiaco all'epoca di S. Benedetto. Note di topografia. Benedictina 28: 69-80.

Quattrocchi, Claudia. 2018. Un martire inglese alla curia di Roma. L'oratorio di San Thomas Becket di Canterbury nella cattedrale di Anagni. Roma: Campisano Editore.

Renier, Jean Simon. 1855. Imagerie du Sacro Speco. Roma: RCA.

Riccioni, Stefano, and Karina Querijo. 2012. La perduta decorazione dell'oratorio di San Silvestro a San Martino ai Monti 1219-1227. In Il Duecento e la cultura gotica 1198-1287. Edited by Serena Romano. Milano: Jaca Book, pp. 104-6.

Righetti Tosti-Croce, Marina. 1982. L'architettura del Sacro Speco. In I Monasteri benedettini di Subiaco. Edited by Carlo Giumelli. Milano: Amilcare Pizzi, pp. 75-94.

Romano, Serena. 1992. Eclissi di Roma. Pittura murale a Roma e nel Lazio da Bonifacio VIII a Martino V (1295-1431). Roma: Argos.

Salvi, Guglielmo. 1953. La cappella di San Gregorio al Sacro Speco di Subiaco. Una sua epigrafe discussa e i due supposti ritratti di San Francesco. Rivista Storica Benedettina 22: 1-28.

Salvi, Guglielmo. 1955. Note critiche di storia sublacense. Rivista Storica Benedettina 24: 15-41.

Ševčenko, Nancy Patterson, and Marina Falla Castelfranchi. 1997. Ad vocem Nicola, santo. In Enciclopedia Dell'arte Medieval. VIII. Roma: Treccani, pp. 679-83.

Webster, Paul. 2016. Introduction. The Cult of St. Thomas Becket: An Historical Pilgrimage. In The Cult of St Thomas Becket in the Plantagenet World, c. 1170-c.1220. Edited by Paul Webster and Marie-Pierre Gelin. Woodbridge: The Boydell Press, pp. 1-24. 